\title{
Sex Ratio, Length-Weight Relationship And Condition Factor Of Ethmalosa Fimbriata In The Cross River Estuary, Nigeria.
}

\author{
${ }^{1}$ Ajah, P.O., ${ }^{2}$ Asuquo P. E \\ ${ }^{I}$ Faculty of Oceanography, University of Calabar, Nigeria \\ ${ }^{2}$ Departments of Zoology and Environmental Studies, University of Calabar, Nigeria.
}

\begin{abstract}
A total of 855 samples of Ethmalosa fimbriata were collected from the Cross River Estuary between January to August 2014 for length-weight, sex ratio and condition factor determinations. The males dominated the populations with a total of 315 followed by 304 juveniles and 236 females with a corresponding sex ratio of 1:1:1.3. E. fimbriata exhibited negative allometric growth pattern with exponent $b=2.303, a=0.086$ indicating that the growth was not proportional in all directions and that the species was slimmer as it grows. The mean condition factor revealed that the species was in good condition with a corresponding values of $0.81 \pm 0.147$, $0.978 \pm 0.745,0.98 \pm 0.121,1.22 \pm 1.38$ and $1.06 \pm 0.84$, respectively, for the males, the females, the pooled sex, juveniles and the three categories merged together. The variations in growth of E. fimbriata could be attributed to climate change and prevailing ecological conditions of the environment.
\end{abstract}

Key Words: Ethmalosa fimbriata, sex ratio, length-weight, condition factor

\section{Introduction}

Ethmalosa fimbriata a Clupeid fish popularly known as Bonga is found almost everywhere in African waters with salinity ranges of $1 \%$ to about $38 \%$. It constitutes $23 \%$ of the catches of artisanal or small scale fishing in the Cross River Estuary and $50 \%$ of the purse-seine fishery in the coastal waters of the Cross River estuary (Ama-Abasi, 2002; 2004).

Several works have been done by several authors on the physiological parameters and the relationship between length and weight of different fish species in different locations (King 1996; Ama-Abasi 2004; Odedeyi et al, 2007; Abowei 2009; Ofem et al 2009; Ajah and Udoh 2012; Obashohan et al 2012; Emmanuel and Rashidat 2013). King (1996) conducted a study on the length and weight relationship of bonga in Nigerian coastal waters and found out that bonga exhibited an allometric growth; Ama-Abasi (2004) faulted this due to the narrow size range and small sample size. Ama-Abasi (2004) on the length weight relationship of bonga in Cross River estuary concluded that it exhibited an isometric growth since the growth was proportional in all directions. Abowei (2009) had a study on the morphology, abundance, length-weight relationship and condition factor of E. agreed with that of Ama-Abasi (2004). Abowei, (2009) on Ilisha africana observed a negative allometric growth pattern. Obashohan et al (2012) on Parachanna obscura, Oreochromis niloticus, Papyrocranus afer, Tilapia mariae and Malapterurus electricus from Ibiekuma stream in Edo state Nigeria found out that these species exhibited negative allometric growth pattern. They also showed that the physiological well-being of the two species $P$. afer and $P$. obscura were below 1.0, an indication that they were not in good condition in their environment but the other three species: M. electricus, $T$. mariae and $O$. niloticus were evidenced by the values of their condition factor. Odedeyi et al (2007) found that elephant fish Mormyrus rume species exhibited an allometric growth pattern. Ajah and Udoh (2012) on the LWR using standard length measurement for both Mugil cephalus and Pseudotolithus elongatus species had lower allometry $(2.734,2.823)$ than those with total length (3.001, 3.145), respectively, for M. cephalus and P. elongatus with condition factors of 0.946 and 1.006 , respectively

Odedeyi et al (2007) noted that the mean condition factor varied with seasons thus indicating that seasonal variations affects condition factor of a fish. More interestingly, they concluded that the condition factor decreases with increase in individual sizes. Oni et al (1983) clearly pointed out that in a fish population, the physiological well-being of a fish constantly vary in a particular period of time and it might be affected by biological and non-biological factors.

Knowledge on the length and weight relationship of Ethmalosa fimbriata in the aquatic ecosystem will be useful in fish management, assist scientifically in checking the reproductive potentials and controlling the exploitation rate of the species in the estuary year in year out and add to the already existing information on the family Clupeidae. It is very important in studying the biology of fresh water and marine fishes and it can be used to foretell weight from length measurements made in the yield assessment (Pauly, 1993). Fish can attain either isometric growth, negative allometric growth or positive allometric growth. Ajah and Udoh (2012) opined that positive or negative allometriesm is a function of whether or not standard or total length measures were adopted. 
Isometric growth reveals that there is no body change or shape as the organism grows meanwhile a negative allometric growth implies that the fish becomes slimmer as it increases in length. A positive allometric growth means the fish becomes deeper-bodied as it grows (Riedel et al., 2007).

The condition factor of a fish is an important tool in observing its feeding capability, and the rate at which the fish is growing (Anene, 2005; Ajah and Udoh 2012). It is to a large extent affected by biological and non-biological factors and the condition of the environment can be used as an index to evaluate the status of the complex community of the fish. Evaluations of the conditions at different body lengths and weight can give valuable information regarding the maturation and spawning in the life span of the fish, whereas a closer look at condition of a fish at different months can give definite clues regarding the breeding seasons.

The study of sex ratio gives information on the fish life food, rate of growth, size at maturity, parasite infestation, overall population of given species and reveals concinnity the total number of the separate sexes, their profusion and multiplicity in a given population (Vicentini and Araujo, 2003, Morgan, 2008).

Since the work of Ama-Abasi (2004) there has been no report on the fecundity, the physiological wellbeing and the sex ratio of E. fimbriata. There is every need to have regular monitoring of these basic reproductive indices of the species to detect sharp changes, more importantly with the advent of climate change in global warming. This study is therefore conducted to determine the current fecundity rate, condition factor and sex ratio of bonga to find out if there is any major deviation from the work of Ama-Abasi ( 2004) that was done over a decade ago.

\section{Description of the study area:}

\section{Materials And Methods}

This study was carried out in the Cross River Estuary which lies within latitudes $4^{\circ}$ and $5^{\circ} \mathrm{N}$ and longitudes $7^{\circ} 30^{\prime}$ and $10^{\circ} \mathrm{E}$. Ajayi (1998). It is the largest estuary in the Gulf of Guinea covering an estimated area of $54,000 \mathrm{~km}^{2}$ and about $39,000 \mathrm{~km}^{2}$ of the estuary while the remaining $14,000 \mathrm{~km}^{2}$ lies in Cameroon. It also has a long coastline with fringing mangroves of about $960 \mathrm{~km}$ coastline of Nigeria, (Dada and Gnanadoss, 1983,) $129 \mathrm{~km}$ lies in the Cross River Estuary, with a characteristic muddy bottom. (Fig.1).

\section{Collection of samples}

A total of 855 samples of Ethmalosa fimbriata comprising 236 females, 315 males and 304 juveniles were collected from January to August under fresh conditions from the catches of artisanal fishery at Ibaka beach, a major landing point in the outer estuary.

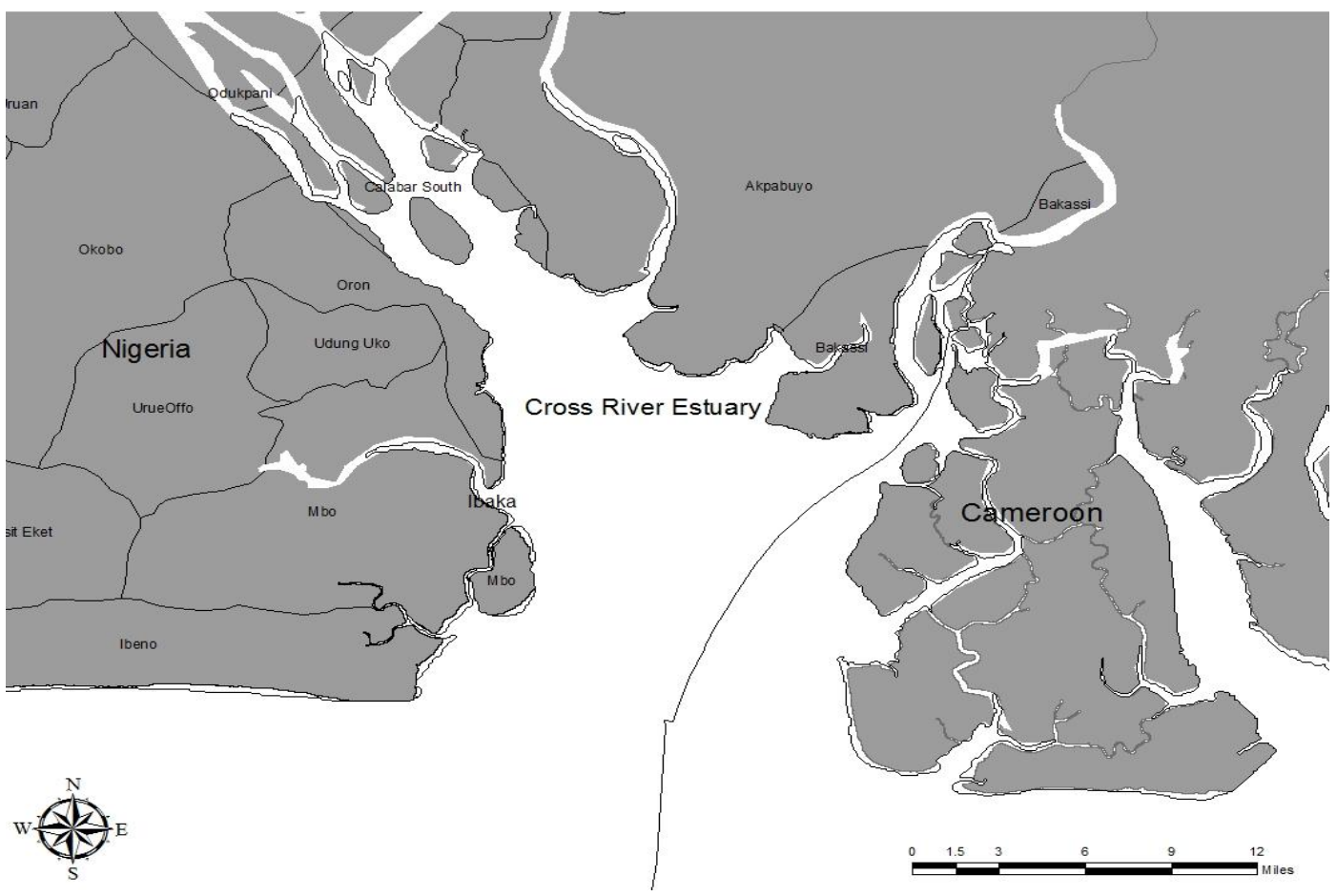

FIG. 1: Map showing the study site 


\section{Identification of the fish species and their sexes}

Identification of Ethmalosa fimbriata was based on the identification key given by Fischer et al. (1987) and sexes were differentiated based on internal features such as gonad. The fish was cut open to determine sexes by physical examination of the gonads.

\section{Measurement of biometric indices of Ethmalosa fimbriata}

The following parameters were measured accordingly for each specimen. The Total length was measured in centimeters while the total weight was measured in grams. Measurement of the total length of the fish was taken from the snout to the tip of the caudal fin using a calibrated meter rule in centimeters. Metlar 2000D electronic weighing balance was used to obtain the weight of the specimens in grams.

\section{Determination of length-weight relationship and condition factor}

Calculations were first made for the males, females and the juveniles of bonga thereafter the three sets of the data were pooled together for the determination of the parameters.

The expression $\mathrm{W}=\mathrm{aL}^{\mathrm{b}}$ was used in the determination of the length (L) and weight $(\mathrm{W})$ relationship (Pauly, 1984)

Where

$$
\begin{aligned}
& \mathrm{W}=\text { the weight of the fish }(\mathrm{g}) \\
& \mathrm{L}=\text { the total length of the fish }(\mathrm{cm}) \\
& \mathrm{a}=\text { constants, } \mathrm{b}=\text { exponent of the length weight relationship. }
\end{aligned}
$$

"a" and "b" values will be gotten from a linear regression in the graph of the length and weight of the fish.

Determination of condition factor $(\mathbf{k})$ for the males, females and pooled sex of E. fimbriata using: $\mathrm{K}=100$ $\mathrm{W} / \mathrm{L}^{3}$

\section{Statistical analysis}

Where: $\mathrm{K}=$ condition factor, $\mathrm{W}=$ weight of fish (gm) and $\mathrm{L}=$ length of fish (cm)

The nature and degree of relationship between the length and weight of the males and females and pooled sexes of E. fimbriata were determined using a correlation and regression analysis. One way analysis of variance (ANOVA) was used to test for significance of the value of $b$ and the condition factor of the species.

\section{Results}

A total of 855 samples of E. fimbriata were collected between January and August from the Cross River Estuary comprising of males, females and juveniles. In this study the minimum size was $3.9 \mathrm{~cm}$ and the largest size for the length weight relationship was $30.0 \mathrm{~cm}$ giving a very wide range of $26.1 \mathrm{~cm}$. The size range in the determination of the sex ratio was between $12 \mathrm{~cm}$ to $30.0 \mathrm{~cm}$. The males were found to range from $12.3 \mathrm{~cm}$ to $30.0 \mathrm{~cm}$ in total length and $90 \mathrm{~g}$ to $285 \mathrm{~g}$ in weight. For the females, the total length and weight ranged was between $15.9 \mathrm{~cm}$ to $29.6 \mathrm{~cm}$ and $40 \mathrm{~g}$ to $254 \mathrm{~g}$ respectively giving an indication that the males were slightly bigger than the females in length. The overall population showed that the males were 315 while the females were 236 with a ratio of male to female as 1:3

The length and weight relationship for Ethmalosa fimbriata in the Cross River Estuary are shown in figures 2,4,6,8 and 10 with their corresponding values for each category. The log transformation of the length and weight relationship of the different categories (i.e Male, Female, combined sex, Juveniles and the three categories pooled together) are shown in figures 3,5,7,9 and 11. The equation thus derived in respect of lengthweight relationship is as follows:

$$
\begin{aligned}
& \text { Female } \quad \mathrm{W}=0.017 \mathrm{~L}^{2.814}, \mathrm{R}^{2}=0.928 \text { (Fig. 2) } \\
& \text { Male } \quad \mathrm{W}=0.026 \mathrm{~L}^{2.6836} \mathrm{R} 2=0.701 \text { (Fig.4) } \\
& \text { Combined sex (Male and female only) } \mathrm{W}=0.02 \mathrm{~L}^{2.772} \mathrm{R}^{2}=0.814 \text { (Fig.6) }
\end{aligned}
$$$$
\text { Pooled sex (Male, female and juveniles) } \mathrm{W}=0.086 \mathrm{~L}^{2.303} \mathrm{R}^{2}=0.862 \text { (Fig.8) }
$$$$
\text { Juveniles } \quad \mathrm{W}=0.79 \mathrm{~L}^{1.513 \mathrm{R} 2}=0.679 \text { (Fig.10) }
$$

The corresponding logarithmic regression equation for the male, female, combined sex, juveniles and the three categories pooled together is represented as follows

- The logarithmic regression equation for the female sex $=\log \mathrm{W}=2.814 \pm 1.752 \log \mathrm{L}(\mathrm{R} 2=0.928)($ Fig. 3$)$

- The logarithmic regression equation for the male sex

$$
=\log \mathrm{W}=2.683 \pm 1.580 \log \mathrm{L}\left(\mathrm{R}^{2}=0.701\right) \text { (Fig.5) }
$$

- The logarithmic regression equation for the combined sexes of $E$. fimbriata (male and female)

$$
=\log \mathrm{W}=2.772 \pm 1.698 \log \mathrm{L}\left(\mathrm{R}^{2}=0.814\right) \text { (Fig. 7) }
$$

- The logarithmic regression equation for the three categories: male, female, and juveniles.

$$
=\log \mathrm{W}=2.303 \pm 1.064 \operatorname{LogL}\left(\mathrm{R}^{2} 0.863\right) \text { (Fig.9) }
$$

- The logarithmic regression equation for the juveniles

$$
=\log \mathrm{w}=1.513 \pm 0.10 \operatorname{LogL}\left(\mathrm{R}^{2}=0.679\right)(\text { Fig 11) }
$$




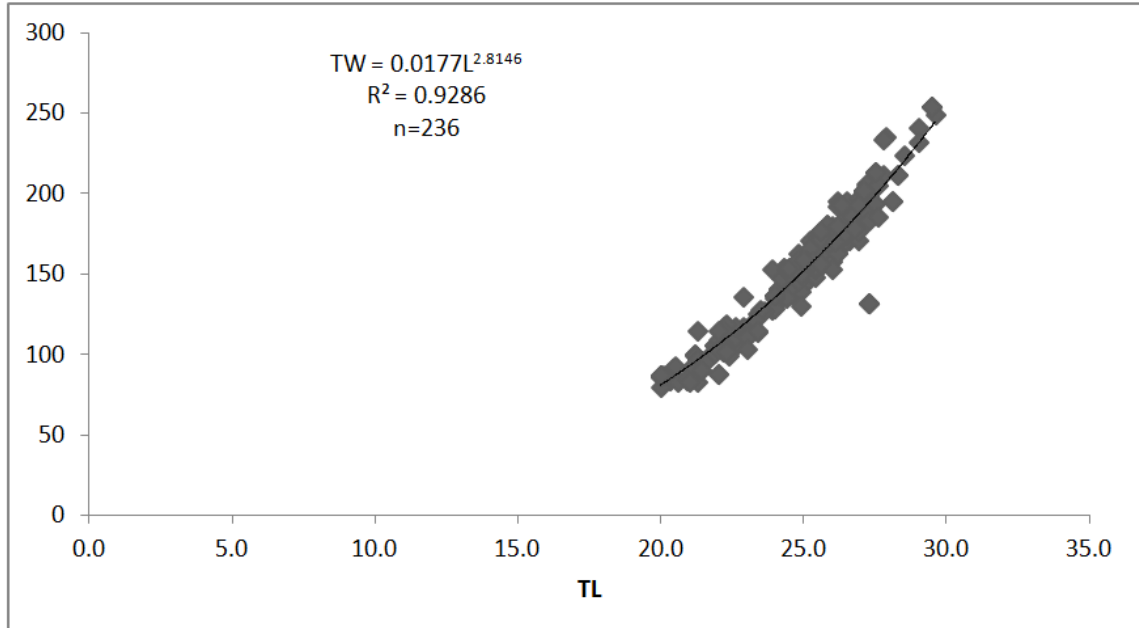

FIG. 2: Length weight relationship of female E. fimbriata

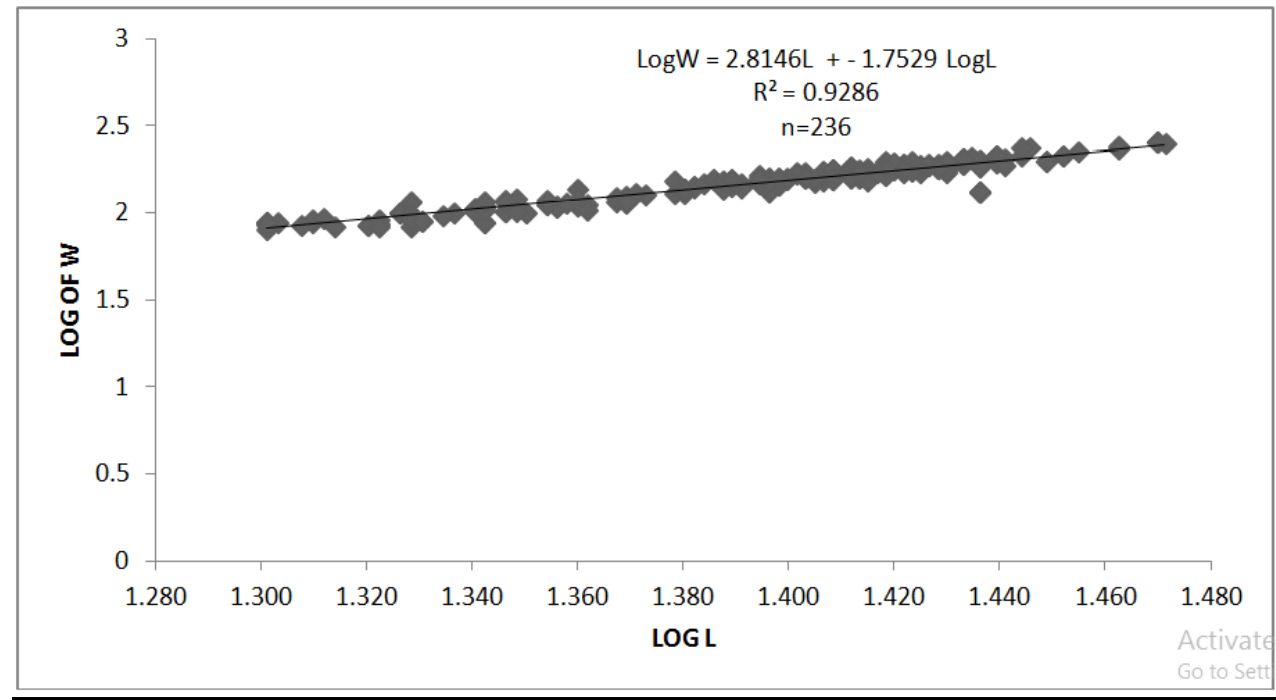

FIG. 3: Log transformed data of Length-weight relationship of female E. fimbriata

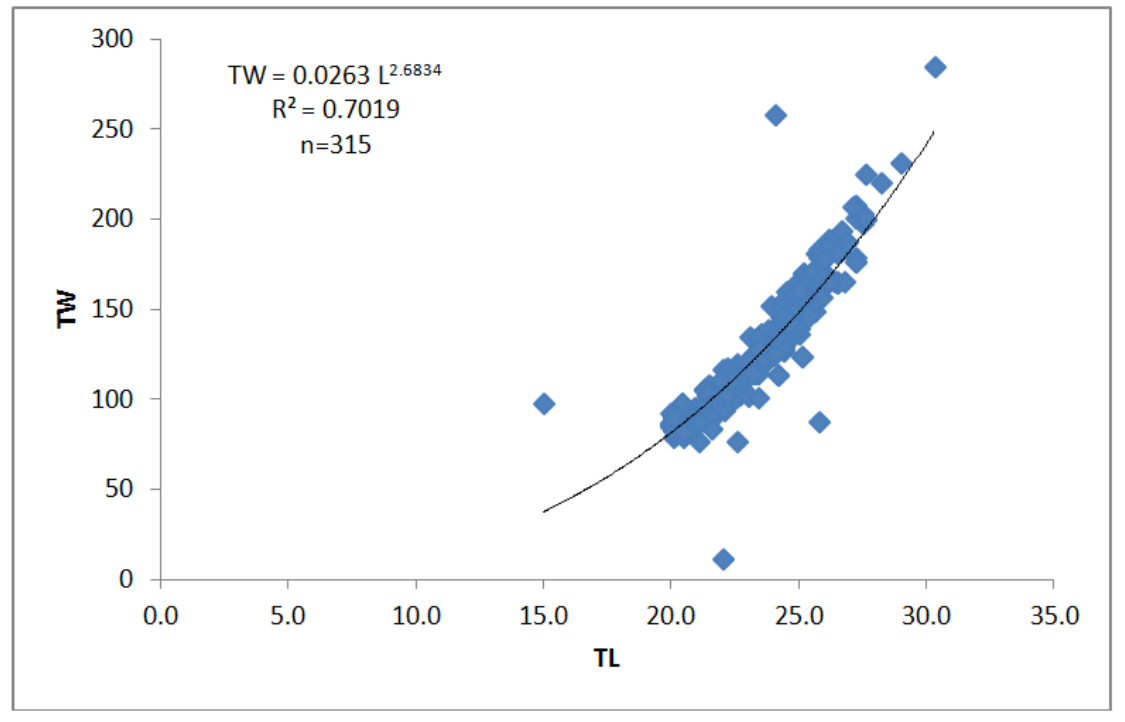

FIG. 4: Length weight relationship of male E. fimbriata 


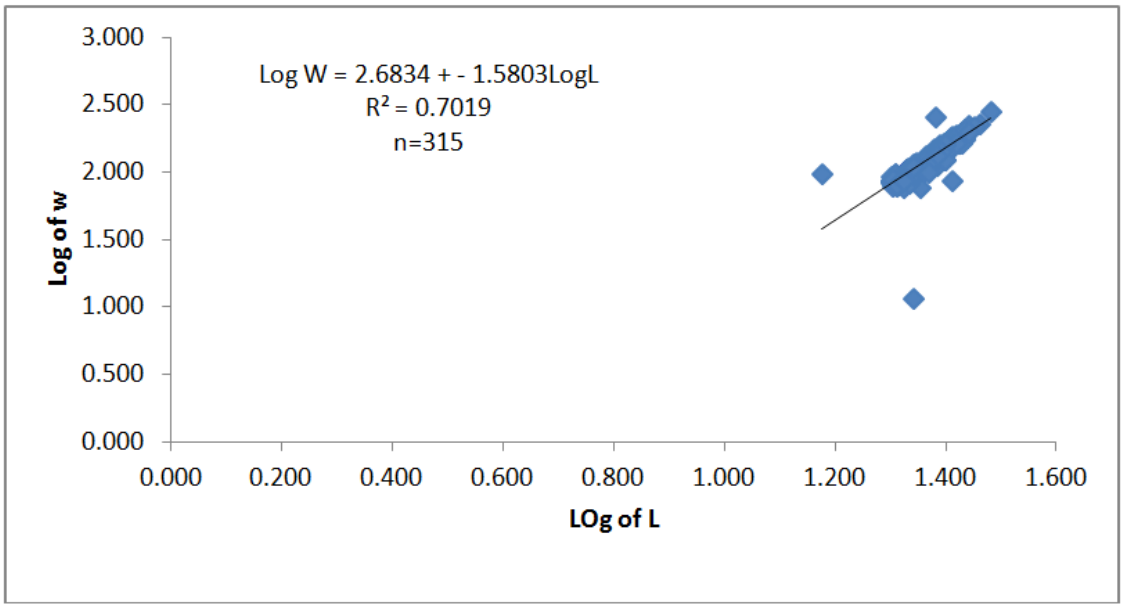

FIG.5: Log transformed data of length weight relationship of male E. fimbriata

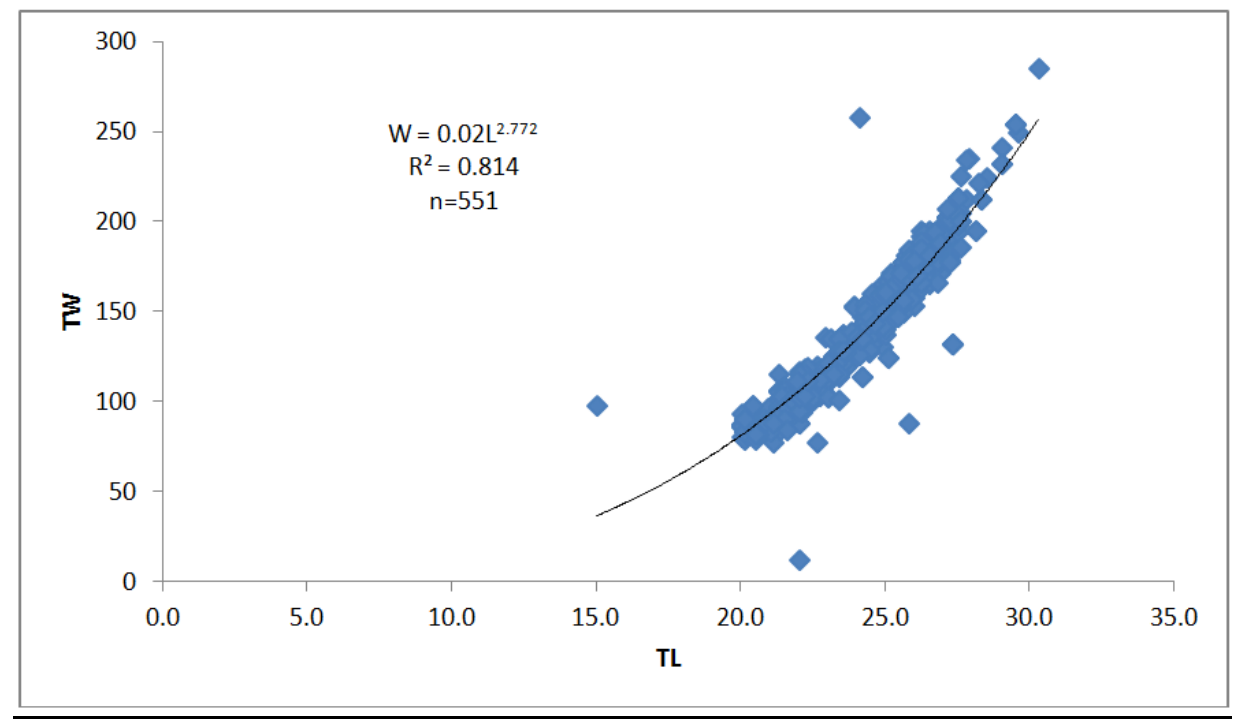

FIG. 6: Length weight relationship of pooled sex ( male and female)

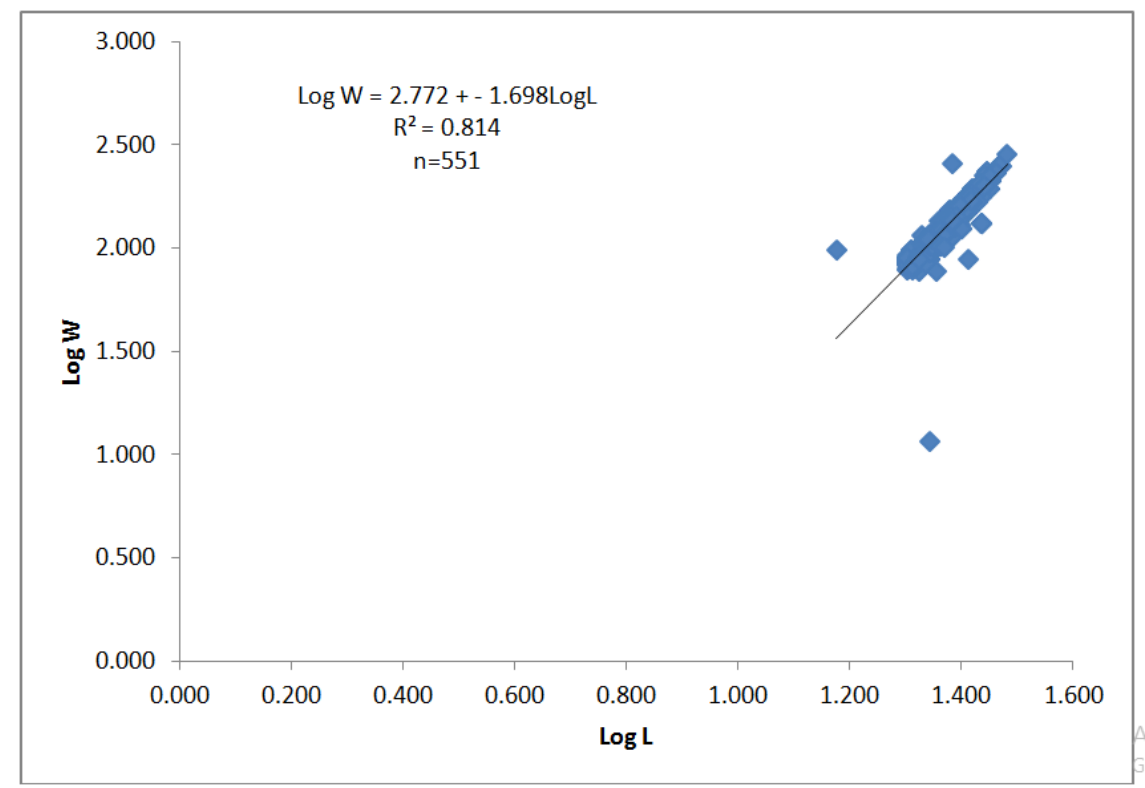

FIG. 7: Log transformed data of length weight relationship (males and females ) of E.fimbriata 


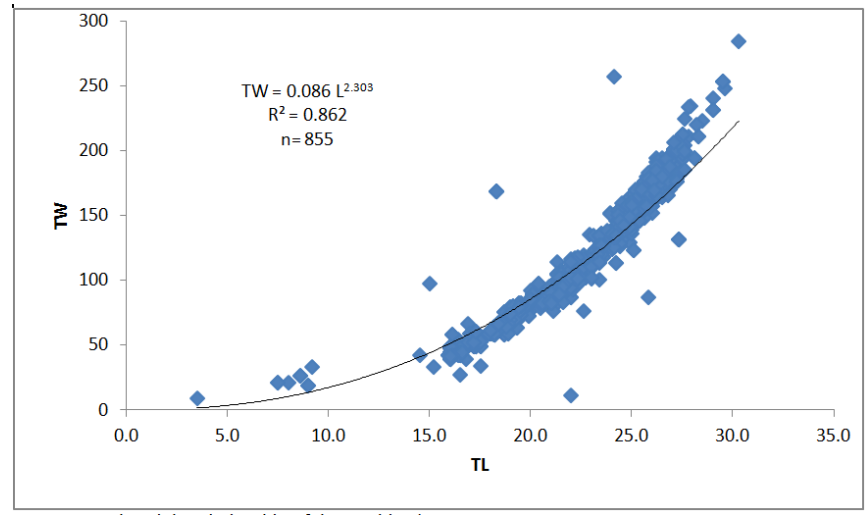

FIG 8: Length weight relationship of the combined sexes (male,female and juveniles)

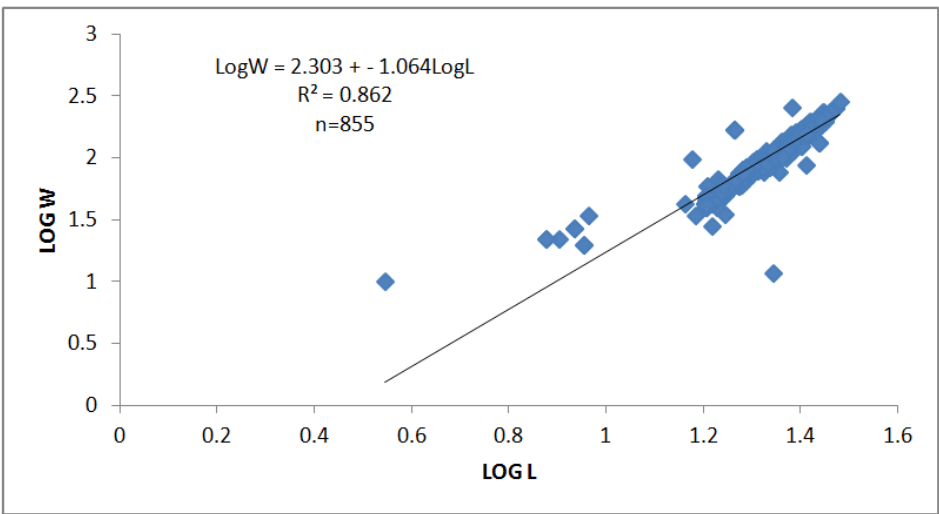

FIG. 9: $\log$ transformed data of length weight relationship of the combined sexes ( male, female and juveniles)

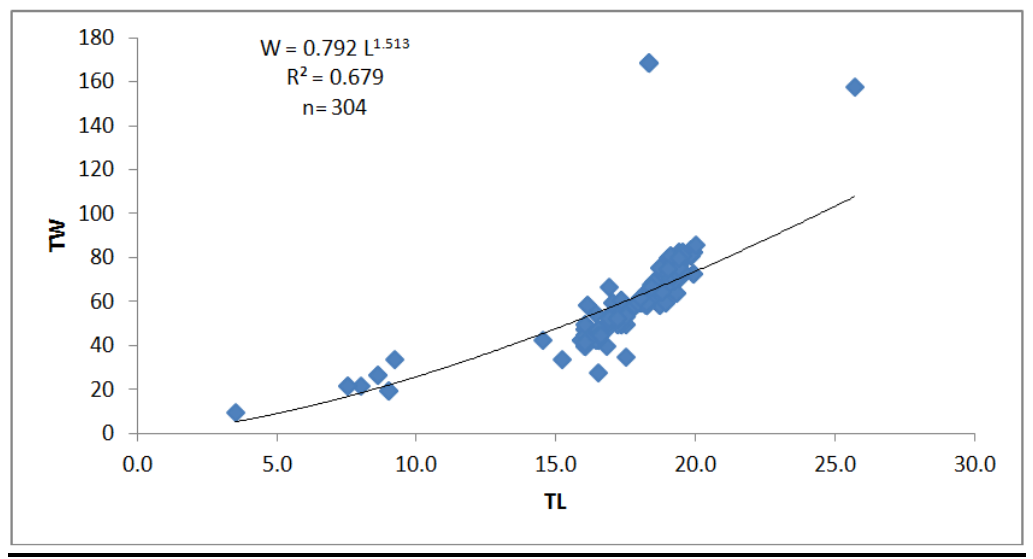

FIG. 10: Length weight relationship of the juveniles of E. fimbriata

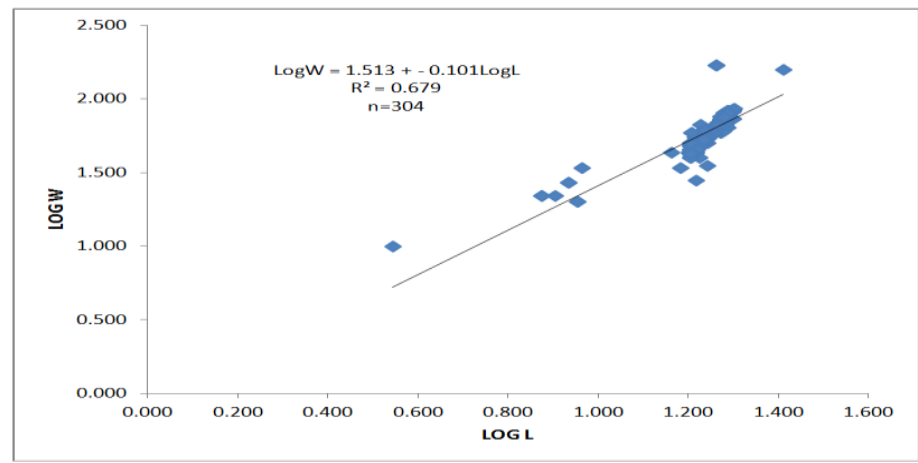


FIG. 11: Log transformed data of length weight relationship of the juveniles of E.fimbriata

\section{Condition factor of Ethmalosa fimbriata}

The condition factor $\mathrm{K}$ for Ethmalosa fimbriata was calculated and examined for the females and it ranged from 0.64 with fish length of $27.3 \mathrm{~cm}$ and weight $132 \mathrm{~g}$ to 1.19 with fish length of $21.3 \mathrm{~cm}$ and weight $115 \mathrm{~g}$. For the males of E. fimbriata the condition factor ranged from 0.096 with fish length of $26.5 \mathrm{~cm}$ and weight $181 \mathrm{~g}$ to 4.83 with fish length of $12.0 \mathrm{~cm}$ and weight $90 \mathrm{~g}$. The mean condition factors were $0.978 \pm 0.075$ for the females, $0.98 \pm 0.15$ for the male, $0.98 \pm 0.122$ for the combined sex (male and female), and $1.22 \pm 1.38$ for the juveniles. The mean condition factor for the three categories, that is, i.e the male, female and juveniles merged together was $1.06 \pm 0.84$ which is above an estimated value for Fulton's condition factor and it is an indication that the species is doing very well and is in good condition. The monthly condition factor (Table 1) showed that the month of March recorded the lowest condition factor during the study.

Table 1: Monthly Condition Factor

\begin{tabular}{|l|l|l|}
\hline Month & Monthly mean condition factor & Total samples \\
\hline January & 0.95 & 61 \\
\hline February & 1.02 & 79 \\
\hline March & 0.02 & 165 \\
\hline April & 1.05 & 142 \\
\hline May & 0.97 & 88 \\
\hline June & 0.98 & 95 \\
\hline July & 1.03 & 56 \\
\hline August & 1.38 & 169 \\
\hline
\end{tabular}

Table 2: The parameters of length -weight relationship of E. fimbriata

\begin{tabular}{llllcc}
\hline Parameters & Males & Females & Males/Females & Juveniles & combined data \\
$\mathrm{a}$ & 0.026 & 0.017 & 0.02 & 0.79 & 0.086 \\
$\mathrm{~b}$ & 2.683 & 2.841 & 2.772 & 1.513 & 2.303 \\
$\mathrm{~K}$ & 0.981 & 0.97 & 0.98 & 1.22 & 1.06 \\
$\mathrm{~N}$ & 315 & 236 & 551 & 304 & 855 \\
\hline
\end{tabular}

\section{Discussion}

The weight of a fish is seen to be directly proportional to length (Weatherly and Gill, 1987; Zafar et al., 2003). For an ideal fish which have an equal proportion of length and weight, the $b$ value may not be less than 3.0. According to Thomas et al (2003) this dimensional equality has occasionally been observed as a value which is higher or lower than 3.0 which points to an allometric growth. Tesch, (1978) stated that a fish becomes lighter or slimmer when there is a deviation from isometry in this case the value is lower than 3.0 (negative allometric growth). On the other hand, if the value is above 3.0 it indicates that the fish has a thicker body meaning that increase in length is directly proportional to the increase in weight (positive allometric growth) (Wooton 1998; Zafar et al (2003). It was evident in this study that the growth of E. fimbriata is allometric. -The $\mathrm{b}$ values for females, males and juveniles as well as the combined sexes showed a negative allometric growth with the general assumption that the specific gravity of the fish remained constant. This corroborated the view of Tesch (1978). More so it was observed in (Figs 2, 4, 6, 8 and 10) that the exponent b value significantly departed from isometric condition for the separate sexes of E. fimbriata, the combined sexes, and even with the juveniles. Interestingly, the b value was higher in the females (Fig. 2) than the males (Fig.4) and it may be due to the enormous growth of ovaries in the females compared to that of the testes in males. In the case of the juveniles, the $b$ value was also observed to be high (Fig. 10) probably due to high feeding intensity of the juveniles. Wooton (1992) pointed out that allometric growth is negative (i.e b is below 3.0) if the fish becomes slender as it grows and positive (i.e. $b$ is above 3.0) if the fish gets plumper as it grows longer. The results of this indicated that bonga did not change shape as it grows longer. This result is in contrasts with King (1996), who drew a conclusion that E. fimbriata exhibited an allometric growth pattern. The sample size the author used was small and the range was low. The widest range was $15.5(15 \mathrm{~cm}-31.5 \mathrm{~cm})$ and the smallest range $2.9(8-10.9$ $\mathrm{cm})$. In this study, the minimum size range was 3 and the largest $30.0 \mathrm{~cm}(3.0-30.0 \mathrm{~cm})$ giving a wide range of $26.1 \mathrm{~cm}$. The negative allometric growth exhibited by bonga in the Cross River estuary may be attributed to changes in ecological conditions in the estuary. Ama-Abasi (2004) reported that the length weight growth of bonga in Cross River estuary was isometric with $b=3.0$ and $a=0.00967$ and the author concluded that from all indications the growth of bonga was proportional in all directions. A comparison with the present study reveals that length weight relationship of bonga departed from the isometric conditions and the length weight growth 
was not proportional. The difference between these findings and that of Ama-Abasi (2004) may be attributed to variations in salinity and ecological conditions in the estuary.

It is important to note that positive or negative allometriesm of any fish are not unconnected with the pattern of measurement adopted whether standard length or total length (Ajah \& Udoh, 2012). They found out that the LWR using standard length measurement for both Mugil cephalus and Pseudotolithus elongatus species had lower allometry $(2.734,2.823)$ and positive when with total length $(3.001,3.145)$, respectively.

Out of the 438 samples studied by Ama-Abasi (2004), 109 (24.9\%) were males, 179 (40.9\%) females and $150(34.2 \%)$ juveniles. In this study, a total of 855 samples were collected in which $315(36.8 \%)$ were males, $236(27.6 \%)$ females and $304(35.6 . \%)$ juveniles. Variations may also be attributed to changes in ecological conditions such as water quality, food availability etc. as reflected in the range of condition factor obtained in the study. The Correlation and regression co-efficient of length- weight relationship was significant and positively correlated. One of the characteristics of length-weight relationship is that when weight is observed to be isometric $(b=3.0)$ the parameter (a) can be interpreted as the condition factor of the fish by multiplying it by 100 but in the case were b is not equal to 3.0 the value (a) ceases to be an index of condition factor (Enin 1994).

The physiological conditions and the well-being of a fish are influenced by meteorological, oceanographic and biometric parameters (Ama-Abasi 2007). This also affects the length frequency distribution as well as the relationship between the length and weight of a fish. The mean condition factor for the males, females and juveniles showed that the fish was actually doing well. Even when the three groups were pooled together it still indicated that the species was doing very well unlike the values obtained for the weight-length relationship by Abowei (2009) and Ama-Abasi (2004) who both concluded that bonga exhibited an isometric growth pattern. Both isometric and allometric growth pattern have been reported by several other authors for different fresh water species in different locations. In Umuoseriche lake, King (1991) concluded in his study that a Tilapia species exhibited an allometric growth pattern. The same author reported an isometric growth for another fresh water species Pseudotolitus elongatus in an estuary. In the Cross River estuary, Ekeng (1990) reported an isometric growth pattern exhibited by E. fimbriata also Marcus (1984), obtained the same result for Ethmalosa from coastal and brackish water of Akwa-Ibom state. Shenouda et al. (1994) reported an isometric growth pattern for Chrysichthys auratus from the southern most parts of River Nile. The present study is comparable to Soyinka and Ebigbo (2012), who reported a positive allometric growth pattern for Ethmalosa and the mean condition factor showed that the fish was actually doing well irrespective of their habitat whether marine, brackish or freshwater. The correlation coefficient for this present study was positive and highly significant for the three categories of Ethmalosa, an indication that changes in standard length and weight of this fish species were proportional in one direction. Nikosky (1963) pointed out that a better physiological state of a fish can be seen in the value of its condition factor. In other words, if the value of the fish condition factor is high, the fish is in better condition. In this study the condition of the males were better than that of the female and their corresponding values were higher than that of the females.

The juveniles recorded the highest condition factor followed by the three category pooled together. The mean condition factor for the juveniles indicated that the species at that level was doing fine though their growth pattern was still allometric. August and February recorded high values of condition factor during the study. King (1995) corroborated a view that several factors responsible for variation in condition factor (K) may be due to the abundance of food, adaptation to the natural environment and development of the gonads. Though there were no much changes in the mean condition factor of the species. There are obvious variations in the wellbeing of a fish, therefore information on the condition or state of the body or bodily functions of the species with respect to its physiological well-being is important. From a nutritional aspect, there are accumulation of fatty degenerations and development stages of the gonads (LeCren, 1951). The mean condition factors for the three categories of this species with the condition factor on monthly basis ranging from 0.016-1.389 which was observed throughout the study is in contrast with the results from previous authors. Ajayi (1982), in his study reported that the value of the condition factor $(\mathrm{K})$ was $=0.77-0.81$ for Clarotes filamentosus in lake Oguta. Abowei (2009) reported $\mathrm{K}=0.94,0.6-1.00$. Ama-Abasi (2004) reported $\mathrm{K}=0.96$ in the Cross River estuary. Ajah \& Udoh (2012) had $\mathrm{K}=0.946$ and $\mathrm{K}=1.006$, respectively, for Mugil cephalus and Pseudotolithus elongatus. These differences not withstanding Oni et al, (1983) pointed out that for a particular population over a specific period of time the physiological well-being of any species is never constant and this may be a resultant effect of biological and non-biological factors such as the frequency of feeding and the gonad maturity state (Saliu, 2001). The monthly abundance and sex ratio between the males and females showed that the males dominated in 5 months more than the females in 2 months. In the estuary, the abundance expressed as a percentage for the males was $58 \%$ while the females was $41 \%$ and the sex ratio was in favour of the males. The sex ratio being in favour of males could be as a result of the males moving around in search for food and the differences in the growth of the separate sexes (Panfili et al., 2004). It is an undisputable fact that sex ratio usually reflects the 
acclimation process in food availability which also depends on the density. In the present study the population of males was more than that of the females. This may be due to upstream migration into the sea.

\section{Summary, Conclusion And Recommendations}

This work has highlighted the sex ratio, length weight relation and condition factor of Ethmalosa fimbriata in the Cross River estuary. The mean monthly indices of condition, $\mathrm{K}$ values shows that there was an improvement in fish condition between February, April, July and August.(wet and dry season) the highest condition factor was recorded in August. In the period of the rainy season, the species experienced favourable condition due to abundance of food and improvement during the stages of development of the gonads (Gomiero and Braga, 2005). The b value was 2.303 and growth for this species was a negative allometric growth pattern. And this is attributed to variations in water quality parameters, sample size and several ecological conditions of the environment.

This observation agreed with the findings of Welcomme (1979) and Fagbenro et al. (1991). Both authors reported the same thing for many freshwater fishes in Africa. Lagler et al. (1977) related such differences in seasonal values of condition to availability and abundance of food supply, timing and duration of breeding cycle; physiological stress caused by changes in water quality properties within the habitat; sexual differences, age; changes in seasons and gonad maturity stages in fish.

Variations in the monthly fish condition observed in this study may be attributed to the availability of natural food in the habitat consequent upon flooding during the rainy season which resulted in the inundation of previously dry ground thereby altering a number of water quality properties which ensured growth and production of natural food. The negative allometric growth implied that the fish species did not increase in weight as it grows meaning that the fish grew longer but thinner in body size; growth was not proportional in the senses that the increase in length was not proportional to body size. There are also suggestions that fish condition can be influenced by certain extrinsic factors such as changes in temperature and photo period (Samat et al 2008). That length-weight relationship in fish may be affected by some factors which include gonadal development and maturity, sex, diet composition, stomach fullness, health, and preservation techniques as well as season and habitat were not taken into consideration in the present investigation. Nevertheless, the mean condition factor observed in this study indicated that the species is in good condition.

\section{Conclusion}

From this study, it is concluded that Ethmalosa fimbriata is an important food fish in Africa and it is a highly exploited species. Owing to different ecological and anthropogenic threat, the growth of E. fimbriata in the Cross River estuary is slightly affected and a mass awareness is highly needed among the fishers about the ongoing threat to permit better management and survival of this species in the near future. There exist some differences between this work and that of Ama-Abasi (2004) ten years ago. Ama-Abasi reported that bonga has isometric growth conditions in the Cross River estuary but this work showed that the growth of bonga is a negative allometry. This may possibly be attributed to climate change and other ecological conditions.

\section{Recommendations}

The resultant variation in the ecological conditions in the estuary has affected the growth of E. fimbriata in the Cross River estuary. However, future work has to be done on the length weight relationship of bonga with emphasis on the influence of climate change and the collation of basic meteorological and oceanographic parameters which were not part of this work.

\section{References}

[1]. Abowei, J. F. N. (2009). The morphology, abundance, condition factor and length weight relationship of Ethmalosa fimbriata from Nkoro River, Niger Delta Nigeria. Advance Journal of Food Science and Technology, 1(1): 51-56,

[2]. Ajayi, T. O. (1982). The age and growth of the tongue sole Cynoglossus canariensis (Stend, 1998). In: Proceedings of the Fisheries Society of Nigeria (FISON) New Bussa, 2: (19):30-34

[3]. Akintola, S. L, Anetekjai, M. A., Fakoya, K. A., Adewolu, M. A. (2010). Seasonal distribution and aspects of biology of Genus Macrobrachium from Badagry Creek, Nigeria. Nigerian Journal Fisheries, 7 (1- 2): 16 - 24.

[4]. Ama-Abasi, D. (2002). Aspects of Population biology of the bonga, Ethmalosa(Bowdich, 125) in the Cross River Estuary, Nigeria. Ph.D. Thesis, University of Calabar, Calabar. $\quad 179 \mathrm{pp}$.

[5]. Ama-Abasi, D. E. 2004. Length weight parameters and condition factor of bonga, Ethmalosa fimbriata in the cross river estuary, Nigeria Global Journal of Pure and Applied Science, 10(3): 379-383.

[6]. Ama-Abasi, D. (2007).A review of length-weight relationship and its parameters in aquatic species. In: Proceedings of the 22nd Annual Conference of the Fisheries Society of Nigeria, Kebbi, Kebbi State, Nigeria. 12 ${ }^{\text {th }}-16^{\text {th }}$ November, 2007, 240-244pp.

[7]. Anene, A., (2005). Dietary components of stomach of Tilapia Mariae Boulenger of Umoseriche lake, Imo state Nigeria. Journal of Aquaculture and Aquatic Science, 5: 43-47

[8]. Dada, B. F \& Gnanadoss D. A. S (1983). Nigerian fisheries development challenges and opportunities of the 1980s.Proceeding of the $3^{\text {rd }}$ Annual Conference of the fisheries society of Nigeria 22-25 February 1983 Maiduguri, 14-24pp

[9]. Ekeng, E. O, (1990). Length-weight and diet composition of Ethmalosa fimbriata (Bowdich). Pliscea: clupeidae in Cross River estuary, Nigeria. Bachelor of Science Project, Biological Science Department, University of Calabar. Cross River State, Nigeria, pp: 36. 
[10]. Emmanuel, O. L. \& Rashidat, T. O, (2013). Growth pattern, sex ratio and fecundity estimate in blue crab Calinectes amnicola. Advances in Life Science and Technology, 7 (1): 38-42

[11]. Enin, U. I. (1994). Length weight parameters and condition factor of two West African prawns. Review of Hydrobiology in the Tropics, 27(2):121-127

[12]. Fagbenro, O. A., Olaniran, T. S. \& Esan, A. O. (1991). Some aspects of the biology of the catfish, Heterobranchus bidorsalis Geoffrey saint-hillarie 1809 (Claridae) in river Ogbese, Nigeria.Journal African Zoology, 105:363-3 72.

[13]. Fischer, W., Bauchot, M. \& Schneider, M. (1987). Fisches FAO D'Identification des especespoun les besoins de la peche (Revision 1) mediterranee et mer Noire. Zone de perche 37. Volume II Vertebres. Publication preperee la fao. Resultat d'un accordentre in FAO et la commission des cornrnunautes Europeennes, 2:761-1530.

[14]. Gomiero, L. M. \& Braga, F. M. S (2005). The conditions factor of fishes from the River 5 basins in Sao Paulo southeast of Brazil Act. Science Maringa, 27 (1):73-78

[15]. King, R. P. (1991). The biology of Tilapia niariae Bovlenger 1899 (Perciformes: Cihlidae) in a Nigeria, Rainforest stream. Ph.D Thesis, Department of Zoology, University of Port-Harcourt, Nigeria, pp :102-105.

[16]. King, M. (1995). Fisheries biology, assessment and management. Fishery news books oxford

[17]. England, 341pp.

[18]. King, R. P. (1996). Population dynamics of the mud skipper, Periophthalmus barbarus

[19]. (Gobidae) in the estuarine swamps of Cross River.Nigerian Journal of Aquatic Science,

[20]. 11:31-34

[21]. Lagler, K. F, J. E. Bardach, R. R, Muller \& D. R. May Passino. (1977). Ichthyology $2^{\text {nd }}$ edition Wiley, New York., 506pp

[22]. LeCren, E. D. (1951). The length-weight relationship and seasonal cycle in gonad weight and condition in the perch Percaj luviatilis. Journal of Animal Ecology, 20(2): 201-219.

[23]. Marcus, C. (1984). Biology of bonga fish; Ethmalosa fimbriata (Bowdich): in the Nigeria Coastal and brackish waters project (NF) 1,2. Annual Report, Nigeria Institute for Oceanography and Marine Research Lagos, pp: 232

[24]. Morgan, M. J. (2008). Integrating Reproductive Biology into Scientific Advice for Fisheries Management. Journal Northwest Atlantic for Fisheries Science, 41:37-51.

[25]. Nikolsky, G. V. (1963). The ecology of fishes Academy Press, London and New York

[26]. Obashohan, E. E Imasven, J. A. \& Isidahome, C. E (2012). Preliminary studies of the length weight relationship and condition factor of the fire fish species from Ibiekuma stream, Ekpema, Edo state. Journal of Agriculture research and development, 2 (3): 061-069

[27]. Odedeyi, O. O., Fagbenro, O., Bello-Olusoji, O.,\& Adebayo, O. (2007). Length weight relationship and condition factor of elephant fish, mormyrus rumein River Osse, South Western Nigeria — Animal Research International, 14 (1): $617-620$.

[28]. Oni, S. K., Olayemi J. Y. \&Adegboye, J. D. (1983).The comparative physiology of three ecologically (Rupel). Synodontis schall. Block and Schneider and Tilapia zilli (Gervais). Journal of Fish \& Biological Science, 22: 105-109.

[29]. Panfili, J., Mbow A, Durand J. D., Dioprkk, Dioufk, Thior D, Ndiaaye \& Lae P, (2004). influence of salinity on the life history traits of the west African black-chined tilapia (sarotherodon melanotheron). Comparison between the Gambia and Saloum estuaries: Aquatic living Resources, 17:65-74.

[30]. Pauly, D. (1984). Fish population dynamics in tropical waters: A manual for use with programmable calculators. International Center for Living Aquatic Resources Management (ICLARM) Studies and Reviews, Manila, Philippines, 325 pp

[31]. Pauly, D. (1993). Linear regressions in fisheries research Journal of the fisheries research board of Canada, 30:409-434

[32]. Riedel, R., Caskey, L. M. \& Hunbert, S. H., (2007). Length weight relations and growth rates -3 of dominant fishes of the salt on sea, implication for predation by fish eating buds. Lake and Reservoir Management, 23:528-535

[33]. Saliu, J. K. (2001). Observation on the condition factor of Brycinus nurse (Pisces: Cypriniformes, Characidae) from Asa Reservior, Ilorin, Nigeria Tropical Freshwater Biology, 10: 9-17.

[34]. Samat, A., Shukor, M. N., Mazlan, A. G., Arshad, A. \& Fatimah, M. Y. (2008). Length-weight Relationship and Condition Factor of Pterygoplichthys pardalis(Pisces: Loricariidae) in Malaysia Peninsula. Research Journal of Fisheries and Hydrobiology,3(2): 48-53.

[35]. Shenouda, T.S., F.A. Faten, M R. Mahmoud \& Ray, M.M. (1994). A detail study on age and growth for Chrysichthys auratus and Chrysichthys rueppelli from the southernmost part of the River Nile (Egypt). J. Egypt Ger. Soc., 200(1412): 73-101.

[36]. Soyinka, O. O. A. \& Ebigbo, C. H. (2012). Species diversity and growth pattern of the fish fauna of Epe lagoon, Nigeria. Journal of Fisheries and Aquatic Science, 1: 392-401pp

[37]. Tesch, F. W. (1978). Age and growth. In: RICKER, W. E. (Ed.). Methods for Assessment of Fish reproduction in fresh waters. International Biological Program. (IBP) Handbook No. 3, Blackwell Scientific Publications, Oxford. Pp: 98 - 130.

[38]. Thomas, J., Venn, S. \& Kurup, B. M. (2003).Length-weight relationship of some deep-sea fish inhabiting the continental slope beyond 250m depth along the west coast of India., NAGA, 26(2): 17-21

[39]. Vicentini, R. N. \& Araujo, F. G. (2003). Sex Ratio and Size Structure of Micropoganias furnieri (Desmarest 1823) (Perciformes, Sciaenidae) in Sepetiba bay, Rio de Janeiro, Brazil. Journal of Biology, 3:559-566.

[40]. Weatherly, A. H. \& Gill, H. S. (1987).The biology of fish growth. Academic Press, London, 443 pp.

[41]. Wooton, R. J. (1992).Fish ecology: Tertiary level biology. Blackie. Lonx z5xdon. 212 pp.

[42]. Wooton, R. J. (1998). Ecology of Teleost Fishes. 2 Edition. Kluwer academic publishers, Dordrecht Netherlands, 392 pp

[43]. Zafar, M., Mussadeq, Y., Akhter, S. \& Sultan, A. (2003). Weight-length and condition factor relationship of Thaila, Catla catla from Rawal Dam Islamabad, Pakistan. Pakistan Journal of Biological Sciences, 6 (17): 1532- 1534 